Rui P. Moreno

Andrew Rhodes Jean-Daniel Chiche

\section{The ongoing H1N1 flu pandemic and the intensive care community: challenges, opportunities, and the duties of scientific societies and intensivists}

Received: 1 October 2009

Accepted: 6 October 2009

Published online: 20 October 2009

(C) The Author(s) 2009. This article is published with open access at Springerlink.com

\section{R. P. Moreno (匹)}

Unidade de Cuidados Intensivos Polivalente,

Hospital de St. António dos Capuchos,

Centro Hospitalar de Lisboa Central, E.P.E,

Lisbon, Portugal

e-mail: r.moreno@mail.telepac.pt

Tel.: +351-3153784

\section{A. Rhodes}

Department of Intensive Care Medicine,

St George's Healthcare NHS Trust,

London SW17 0QT, UK

e-mail: andyr@sgul.ac.uk

Tel.: +44-2087255699

\section{J.-D. Chiche}

Service de Réanimation Médicale,

Hôpital Cochin (AP-HP), Université Paris Descartes,

Unité Inserm U567,

75014 Paris, France

e-mail: jean-daniel.chiche@cch.aphp.fr

Tel.: +33-1-58412739

This year has brought a new challenge to Intensive Care Medicine. The current influenza A (H1N1) pandemic may have a disproportionate effect on the provision of Intensive Care services in Europe. These challenges cause many anxieties for practicing clinicians, both as to what to expect, how to practice and what support or help they will be given. In this statement from the European Society of Intensive Care Medicine (ESICM), we aim to describe some of the facts, the fears and the areas where scientific societies can help to improve our understanding of these problems and at the same time reduce the impact of these issues for our members and their patients.

\section{The facts}

In 2009, a new acute respiratory disease emerged in Mexico, secondary to a swine-origin influenza A (H1N1) virus (S-OIV). Public health agencies did their best to contain the dissemination of the disease; however, unfortunately these efforts failed, and on the 11 June, the World Health Organization (WHO) declared the first flu pandemic since 1968 . The disease spread rapidly across the globe. In the southern hemisphere, Intensive Care faced an unprecedented challenge with as many as $25 \%$ of all ICU patients in Australia and New Zealand having either suspected or confirmed S-OIV by the middle of August [1]. In the Northern hemisphere, the first wave of the pandemic had a very heterogeneous impact, with the USA, Canada, England and Spain being especially affected. By the end of August, virtually all countries had reported cases, and many had also reported deaths.

Very early, it became clear that a significant number of deaths were preceded or caused by rapidly developing acute respiratory failure often refractory to conventional mechanical ventilation. Although the vast majority of individuals had a mild illness, similar to seasonal flu, it was observed that certain groups not usually at increased risk of complications or death from seasonal influenza were at special risk for S-OIV. These groups include the pregnant or recent postpartum [2], the obese and the young [3-5]. Three predominant syndromes have been reported $[1,6]$ to be associated with life-threatening situations:

- acute viral pneumonitis with bilateral pulmonary infiltrates ["flu A"-associated acute respiratory distress syndrome (FLAA-ARDS)]; 
- secondary bacterial pneumonia;

- viral exacerbation of airflow limitation.

FLAA-ARDS, the most commonly described of these syndromes, was associated with a very high mortality. Multiple organ dysfunction syndrome (MODS) developed rapidly in up to $75 \%$ of the patients [6], despite the fact that most of these died due to refractory hypoxaemia apparently resistant to the use of measures such as high frequency oscillation and extra-corporeal membrane oxygenation (ECMO) [7]. Approximately half went on to develop life-threatening super-added infections [6], which were especially common in those with co-existing morbid obesity, diabetes mellitus, immunosuppression, malignancy and chronic lung disease [1].

\section{The fears}

Previous influenza pandemics occurred in 1918 (H1N1 strain), 1957 (H2N2 strain) and 1968 (H3N2 strain), resulting in very significant levels of morbidity and mortality. This was especially the case in the pandemic of 1918-1919, which caused major social disruption following the First World War. Today, we can be more optimistic as this current pandemic is unique in respect of two important issues:

1. The state of public preparedness for a pandemic is well in excess of anything previously seen. This has developed following the emergence of severe acute respiratory syndrome (SARS) [8] and the threat of avian flu (H5N1). Major plans have therefore been developed in many countries that could be now implemented $[9,10]$.

2. Since the previous pandemics, Intensive Care Medicine has evolved to enable the treatment of very sick patients presenting with an acute respiratory illness, and we have now new and better antibiotics and antivirals. Modern techniques of mechanical ventilation together with protocols for the support and treatment of multiple organ failure may reduce the overall mortality of these conditions.

Despite the existing plans, the biggest unknown factor remains the overall impact that the pandemic will have both on the health and on the economy. Epidemiologists have been modeling likely scenarios, but the models are notoriously inaccurate early on in a pandemic phase [11]. Using an attack rate ranging from 10 to $30 \%$ of the population with a hospital admission rate close to $1 \%$ and a case-fatality rate close to $0.14 \%$, as in seasonal flu (an hypothesis supported by preliminary data [1]), the pandemic may have a major impact on health services and ICM in particular. Some models have predicted critical care demand at the peak surge of the pandemic to be well in excess of $100 \%$ of available facilities, even in the most developed countries [11]. This is of considerable concern to practicing Intensivists. Increasing intensive care support by a factor of two without additional skilled and trained specialists and without the usual range or technical facilities and support services may well force us to ventilate more patients than normal, but this would not be 'quality critical care.' If this increased surge was to occur, then the numbers of patients presenting would be well in excess of the available capacity to provide them with quality care. This will necessitate triage. The ethics of triage have been discussed several times [12-15], but the concerns as to whether the ethical or legal framework will ultimately support clinicians faced with these tribulations remain. Practicing for a greater good, rather than what is best for an individual patient, may be the pragmatic answer to the problem, but clinicians are rightly concerned that this may lead to future complaint and legal or professional censure. Unfortunately, many national governmental authorities have failed to address these concerns with clear and open guidance.

\section{The resources}

In response to these uncertainties, many groups have started to develop more sophisticated plans based on better data. These plans are now being fed from data acquired by global registries, such as the H1N1 registry, commissioned and developed by the European Society of Intensive Care Medicine (www.h1n1registry.org). Data from this registry will allow real-time trends to be seen and witnessed, which hopefully will enable us to adjust our resources and facilities to be able to cope with a predicted second surge of the disease. Ultimately, more sophisticated analysis will allow us to develop more accurate models for future pandemics that may occur.

In these models, we need to take into account the specificities of this pandemic and the fact that it predominantly affects the young. In many countries the numbers of pediatric intensive care (PICU) beds are at a level far below that of the adult specialty. In addition, PICU has centralized its service in many countries, with the implication that many smaller hospitals no longer have significant skill bases or equipment to care for these children. This may well result in a significant number of young patients being cared for in an adult environment. Even disregarding the problems of putting young patients into an adult unit, the skill and knowledge gap is huge, and this needs to be rapidly addressed to prepare for this eventuality. The close links that exist between the ESICM and the European Society of Paediatric and Neonatal Intensive Care (ESPNIC) will undoubtedly prove to be an important asset to mount a coordinated and efficient response to the current threat.

Even today, many questions remain unanswered, and our understanding of many facets of this pandemic is poor 
[16]. We still know little with regards the pathogenesis or the optimal treatment of the disease. The definition of patients-at-risk remains unclear, and the indications, optimal doses and duration of therapy are not certain. We need better information with regards to the impact of the vaccine in the spread of the pandemic, the use of anti-viral agents, the risks and benefits of steroids or the importance of preemptive antimicrobial therapy. To answer those questions (and many others), several registries and collaborative studies have been initiated. On the back of these registries, together with the established trials groups [such as the European Critical Care Research Network (ECCRN) Trial Group], we hope to be able to initiate and coordinate collaborative interventional research that will increase our knowledge base of this problem.

We contend that such research efforts can and must happen in real time, as the pandemic develops. Indeed, history has shown us that when faced with the most severe of challenges, we usually manage to cope. This often takes courage as well as ingenuity and innovation. Despite the adversities faced and the challenges of working long and stressful shifts, research continues and knowledge base advances. During the SARS crisis in 2002 [17, 18], guidelines for treatment were generated as fast as the disease spread [19], and research output was maintained or even increased. Facing the threat of being infected themselves, clinical teams, often overwhelmed with clinical duties, kept collecting and analyzing data, enabling them to test the best approaches to decrease the morbidity and the mortality of SARS. We would like to thank publicly all of our colleagues that have used their time and efforts to increase our knowledge of this disease, in order to minimize its worldwide impact and to achieve better outcomes for all of our patients. We are certain that the same will happen now.

Despite all of our doubts and the existence of huge heterogeneities between countries, or even regions within countries, the knowledge and availability of ICM is now greater than ever before. It is the duty of scientific societies such as ESICM to foster the development and the dissemination of new knowledge. It is our duty to demonstrate that with this new knowledge Intensivists will be able to improve the outcome of their patients.

Open Access This article is distributed under the terms of the Creative Commons Attribution Noncommercial License which permits any noncommercial use, distribution, and reproduction in any medium, provided the original author(s) and source are credited.

\section{References}

1. Webb SAR, Seppelt IM, for the ANZIC Influenza Investigators (2009)

Pandemic (H1N1) 2009 influenza

("swine flu") in Australian and New

Zealand intensive care. Crit Care

Resusc 11:170-172

2. Jamieson DJ, Honein MA, Rasmussen

SA, Williams JL, Swerdlow DL,

Biggerstaff MS, Lindstrom S, Louie JK, Christ CM, Bohm SR, Fonseca VC, Ritger KA, Kuhles DJ, Eggers P, Bruce H, Davidson HA, Lutterloh E, Harris ML, Burke C, Cocoros N, Finelli L, MacFarlane KF, Shu B, Olsen SJ, the Novel Influenza A (H1N1) Pregnancy Working Group (2009) H1N1 2009 influenza virus infection during pregnancy in the USA. Lancet 374:451-458

3. Perez-Padilla R, de la Rosa-Zamboni D, Ponce de Leon S, Hernandez M, Quinones-Falconi F, Bautista E, Ramirez-Venegas A, Rojas-Serrano J, Ormsby CE, Corrales A, Higuera A, Mondragon E, Cordova-Villalobos JA, the INER Working Group on Influenza (2009) Pneumonia and respiratory failure from swine-origin influenza A (H1N1) in Mexico. N Engl J Med 361:680-689
4. Novel Swine-Origin Influenza A (H1N1) Virus Investigation Team (2009) Emergence of a novel swineorigin influenza A (H1N1) virus in humans. N Engl J Med 360:2605-2615

5. Rello J, Rodriguez A, Lisboa T, Gallego M, Lujan M, Wunderink R (2009) PIRO score for community-acquired pneumonia: a new prediction rule for assessment of severity in intensive care unit patients with community-acquired pneumonia. Crit Care Med 37:456-462

6. Rello J, Rodriguez A, Ibanez P, Socias L, Cebrian J, Marques A, Guerrero J, Ruiz-Santana S, Marquez E, del NogalSaez F, Alvarez-Lerma F, Martinez S, Ferrer M, Avellanas M, Granada R, Maravi-Poma E, Albert P, Sierra R, Vidaur L, Ortiz P, Prieto del Portillo I, Galvan B, Leon-Gil C, The H1N1 SEMICYUC working group (2009) Intensive care adult patients with severe respiratory failure caused by Influenza A (H1N1) in Spain. Crit Care 13:R148

7. Peek GJ, Mugford M, Tiruvoipati R et al (2009) Efficacy and economic assessment of conventional ventilatory support versus extracorporeal membrane oxygenation for severe adult respiratory failure (CESAR): a multicentre randomised controlled trial. Lancet. doi:10.1016/S0140-6736(09) 61069-2
8. Ksiazek TG, Erdman D, Goldsmith C, Zaki SR, Peret T, Emery S, Tong S, Urbani C, Comer JA, Lim W, Rollin PE, Nghiem KH, Dowell S, Ling A-E, Humphrey C, Shieh W-J, Guarner J, Paddock CD, Rota P, Fields B, DeRisi J, Yang JY, Cox N, Hughes J, LeDuc JW, Bellini WJ, Anderson JJ, the SARS Working Group (2003) A novel coronavirus associated with severe acute respiratory syndrome. N Engl J Med 348:1953-1966

9. Hien TT, Liem NT, Dung NT, San LT, Mai PP, Chau NV, Suu PT, Dong VC, Mai LTQ, Thi NT, Khoa DB, Phat LP, Truong NT, Long HT, Tung CV, Giang LT, Tho ND, Nga LH, Tien NTK, San LH, Tuan LV, Dolecek C, Thanh TT, de Jong M, Schultsz C, Cheng P, Lim W, Horby P, for the World Health Organization International Avian Influenza Investigative Team, Farrar J (2004) Avian influenza A (H5N1) in 10 Patients in Vietnam. N Engl J Med 350:1179-1188

10. The Writing Committee of the World Health Organization (WHO) Consultation on Human Influenza A/H5 (2005) Avian influenza A (H5N1) Infection in Humans. N Engl J Med 353:1374-1385 
11. Ercole A, Taylor BL, Rhodes A, Menon DK (2009) Modelling the impact of an influenza A H1N1 pandemic on critical care demand from early pathogenicity data: the case for sentinel reporting. Anaesthesia 64:937-941

12. Christian MD, Hawryluck L, Wax RS, Cook T, Lazar NM, Herridge MS, Muller MP, Gowans DR, Fortier W, Burkle FM Jr (2006) Development of a triage protocol for critical care during an influenza pandemic. Can Med Assoc J 11:1377-1381

13. Hick JL, O'Laughlin DT (2006) Concept of operations for triage of mechanical ventilation in an epidemic. Acad Emerg Med 13:223-229

14. Challen K, Bentley A, Bright J, Walter D (2007) Mass casualty triage: pandemic influenza and critical care. Crit Care 11. doi:10.1186/cc5732
15. Talmor D, Jones AE, Rubinson L, Howell MD, Shapiro NI (2007) Simple triage scoring system predicting death and the need for critical care resources for use during epidemics. Crit Care Med 35:1251-1256

16. Taubenberger JK, Morens DM (2008) The pathology of influenza virus infections. Annu Rev Pathol 3:499-522

17. Booth CM, Matukas LM, Tomlinson GA, Rachlis AR, Rose DB, Dwosh HA, Walmsley SL, Mazzulli T, Avendano M, Derkach P, Ephtimios IE, Kitai I, Mederski BD, Shadowitz SB, Gold WL, Hawryluck LA, Rea E, Chenkin JS, Cescon DW, Poutanen SM, Detsky AS (2003) Clinical features and short-term outcomes of 144 patients with SARS in the greater Toronto area. JAMA 289:2801-2809
18. Fowler RA, Lapinsky SE, Hallet D, Detsky AS, Sibbald WJ, Slutsky AS, Stewart TE, for the Toronto SARS Critical Care Group (2003) Critically ill patients with severe acute respiratory syndrome. JAMA 290:367-373

19. Cooper A, Joglekar A, Adhikari N (2003) A practical approach to airway management in patients with SARS. Can Med Assoc J 169:785-787 